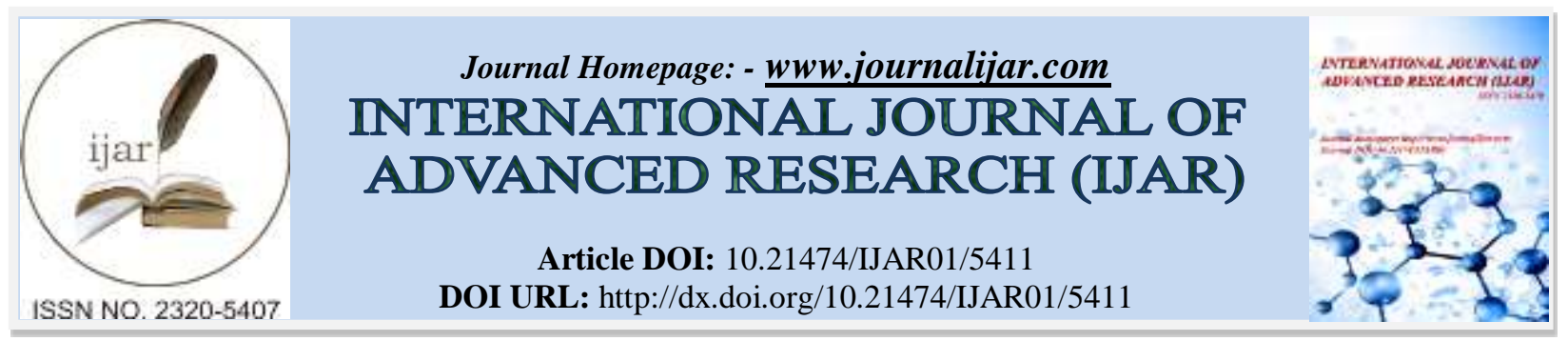

RESEARCH ARTICLE

\title{
REVISITING ENVIRONMENTAL SOCIOLOGY: ITS BEGINNING TO PRESENT STATE.
}

Md. Sayed Uddin (PhD) ${ }^{1}$ and Adam Andani Mohammad (PhD $)^{2}$.

1. Dr. Md Sayed Uddin is Post-Doctoral Fellow in the department of sociology and anthropology of International Islamic University Malaysia (IIUM).

2. Dr. Adam Andani Mohammad, Universiti Malaysia Sarawak UNIMAS, Faculty of Social Sciences.

\section{Manuscript Info}

Manuscript History

Received: 12 July 2017

Final Accepted: 14 August 2017

Published: September 2017

Key words:-

Human ecology environment natural resources pollution deforestation nature.

\begin{abstract}
Sociology has not appeared as one of the core environmental sciences like geography, even though it is one of the social and human sciences. It makes important contribution considering the interest shown by the founders like Durkheim, Weber and Marx in the relationship between human societies and their environment. The direct effect of human activity on the natural world which influences the social realm raised concerns at practical and theoretical levels with issues of hazard, risk and the environment. This desk top case study therefore reviewed literature on the concept and principles and the ways in which environmental matters are discussed within everyday life and sociology. This paper deals with themes of environmental sociology's key concepts and debate on the role of classical theorists in the discipline. It specifically focused on the larger theoretical and conceptual challenge on how the discipline of sociology can usefully address questions of nature and the physical environment and what would this in turn mean for sociology.
\end{abstract}

Copy Right, IJAR, 2017,. All rights reserved.

\section{Introduction:-}

"Environmental problems are considered to be the social aspects of natural problems, and the natural aspects of social problems. The word environment, then, entails both natural and social dimensions."

Jean Guy Vaillancourt. Sociology emerged in response to social problems due to industrialization, urbanization and political situation in the nineteenth century Europe. The discipline has covered every aspect of societal problems to provide better solutions for society. The social practice theories bring to the fore the critical role of the body and material things in all social affairs' (Nicolini, 2012; Shove, Pantzar and Watson, 2012). So social and environmental performance standards specific to distinct sectors like manufacturing, agriculture, fisheries and forestry take a number of forms (Boström et al. 2015). For the pioneers of environmental sociology, nature was primarily considered a sustenance base for human society and defined in accordance with the natural sciences (Schnaiberg 1980; Dunlap 1993; Dickens 1996; Spaargaren 1997; C.S.A. (Kris) van Koppen 2017). However, many scientists claimed that it did not address nonsocial conditions such as environmental quality (Dunlap \& Rosa, 2000, p.800). Dunlap and Rosa stated that environmental sociology emerged from societal attention to problematic conditions including poverty and inequality, racial and gender discrimination and crime and delinquency (Dunlap \& Rosa 2000, p.800). This suggests 
that the future of the environment in developing countries around the world is bleak taken certain issues into considerations. For instance, the livelihood of people in most countries in Africa, Southern Asia and South America depend on arable land, water resources, fish stocks and various forest products. As such, environmental deterioration across the globe led to increase in poverty and decrease in life expectancy particularly in developing countries (UNEP 2006; UNDP, 2005; Vlek, \& Steg, 2007). While the people are devalued due to poverty, the local environment is destroyed as well (Narayan, Patel, Schafft, Rademacher, \& Koch-Schulte, 2000).

The environmental problems encountered by population in the poverty striking areas include deforestation, lack of clean drinking water and heavy urban air pollution. Du Toit (2002) indicate that wildlife resources are in danger or near extinction from unprotected areas considering bush meat hunting in rural communities of developing countries. The paper came up with some basic themes from its development to the present time. Besides, relevant examples were given from the contributions of classical theorists such as Karl Marx (1818-1883) and Emile Durkheim (18581917) regarding the relationship between nature and society. With these different interpretations, it is perhaps the work of Marx and Durkheim that has been most influential in contemporary studies in environmental sociology because of the important foundation laid for social sciences.

There is a debate over the sociology of nature since the emergence of environmental sociology in the 1970s (C.S.A. (Kris) van Koppen 2017). The word environment simply defines "surroundings" (Vaillancourt 1995). Jean Guy Vaillancourt, a Canadian Sociologist, notes that the word "environment" had two different meanings in the past one from psychologists and social scientists, and the other from biologists and natural scientists (Vaillancourt 1995). According to Vaillancourt, the first group viewed the environment as the sum total of outside influences on the human individual and studied how a person's "environment" affected his/her growth, development, and character. The second group used the word to signify the interaction of plants, animals, sunlight, air, and water that collectively makeup "nature"--with nature being generally defined as excluding human creations and influences (Dudley, 2001, p, 11; C.S.A. (Kris) van Koppen 2017). C.S.A. (Kris) van Koppen (2017) indicates that interaction between humans and their natural environment and incorporation of the natural science findings into social action are central to environmental sociology. Environmental constructivism which emerged in the 1980s explained nature as a result of social processes rather than a reality 'out there', thus what people think of as nature is at closer sight a product of social dynamics which was applied to the 'facts of nature' unearthed in scientific experiments (Latour 1993; Callon and Law 1989; Shapin and Schaffer 1985; C.S.A. (Kris) van Koppen 2017). This led to the argument that research and environmental action should aim at understanding and protecting endowed values like moral, aesthetic and others (C.S.A. (Kris) van Koppen 2017; Eckersley 1993; Evernden 1993; Shiva 1993).

In addition, Dunlap and Catton (1979) published an article in the very renowned journal of Annual Review of Sociology entitled "Environmental Sociology", where they defined environmental sociology "as the study of relations between human societies and their physical environments or, more simply, societal-environmental interactions" (Dunlap \& Catton, 1979; Van Der Heijden, 1998). Here, interactions indicate the ways in which humans influence the environment as well as the ways in which environmental conditions (often modified by human actions) influence human affairs, plus the manner in which such interactions are socially construed and acted upon. Sociology sees these interactions as steams from the fact that human populations depend upon the biophysical environment for survival, and this in turn necessitates a closer look at the functions that the environment serves for human beings (Irwin, 2013). Krogman and Darlington (1996) optimistically infer that the considerable work in this area indicates a paradigmatic shift in sociology to theory and research that address the reciprocal nature or interrelations between human populations and the environment" (1996, p.50). Stets and Biga, (2003) support this assertion that environmental sociologists often study environmental attitudes which suggests that individual is important in influencing environmentally responsive behavior.

\section{Method:-}

As a narrative research, an integrative multi-stage critical review of relevant literature is adopted. As such certain publications were selected by specific inclusion criteria on the topic and few articles were identified through references and citations. The articles available in English were selected using keywords, similar terms as well as study title through Google scholar. The search delved much into current studies done between 2003 and 2017, even though articles of historical significance with dates beyond these date were also added. The search was expanded utilizing references and different articles citing to include a lot studies in the review. The criteria for inclusion were to look for; articles and books that explain environmental sociology and the roles of the mains theorists. Besides, 
articles that involve theories, concepts and principles of environmental system were included. By identifying some themes from the existing literature, more than 28 articles were finally selected and reviewed.

\section{Environmental Awareness:-}

William Dudley (2001) the editor of the book titled "The Environment Opposing Viewpoints", in his introduction part emphasizes the awareness of environmental issues, and concludes that the awareness begun in 1960s in both scientific and general public arena. According to him, both the scientists and the general public recognize how human activities always affected natural environments, and how these changes in turn impacted the way humans lived. In addition, a marine biologist and conservation environmentalist, Rachel Carson's very popular book titled "Silent Spring" in 1962 aided environmental awareness in a major way. In her book, she argued that chemical pesticides (DDT) threatened humanity, both by direct exposure and by the destruction of ecosystems (Taylor, 1997). In fact, Carson's book is credited with increasing mass global awareness of the natural environment and culminating in the original Earth day on April 22, 1970; when several million Americans participated in rallies and educational events. Following the event, many attempts were made, beyond traditional conservationist concerns, about national parks and wilderness preservation. Issues like air and water pollution, resource scarcity, and over population were highlighted as such the consequent Earth Day in 1970s revitalized numerous private organizations concerned with environmental preservation. Thus, numerous federal laws were passed and federal agencies created to prevent or mitigate human-caused degradation of the environment. Humphery; Lewis, and Buttel (2002) in their book entitled "Environment, Energy and Society: A New Synthesis" says: The emergence of environmental sociology paralleled the emergence of the environmental movement in the late 1970s. For instance, companies and governments do attempt to greenwash their activities with appealing but ambiguous claims to be environmentally friendly and socially responsible (Lockie, 2016; Sedero and Stoddart, 2015)

\section{Scholarly impact and key concepts of environmental sociology:-}

Lewis and Humphrey (2005) published a very important article entitled "Sociology and Environment: An analysis..." in a very renowned journal, where they stated the impact of the first 25 years of environmental sociology research on current sociology text books. Lewis and Humphrey identified the texts for 40 key concepts in environmental sociology and for the inclusion of work by 20 award winning environmental sociologists. In 2001, environmental sociologists celebrated the $25^{\text {th }}$ anniversary of their American Sociological Association (ASA) section on environment and technology. Leading scholars (Frederick Buttel 2002; Loren Lutzenhiser 2002; Allan Schnaiberg 2002) of environmental sociology attended that anniversary in California. From the symposium one question was asked by majority of presenters: What scholarly impact has 25 years of research in environmental sociology had on sociology in general? The role of environmental sociologists is to specify the ways that societies depend upon the material or biophysical environment, the cultural values and beliefs that prompt people to use the environment in particular ways and the implications of these societal/environmental interrelationships for social consequences and conflict (Lewis and Humphrey, 2005). Sociologist Rudel (2002) published journal article entitled "Sociologists in the Service of Sustainable Development?: NGOs and the Environment - Society Studies in the Developing World". In his paper, Rudel highlighted four themes of environmental sociology like environmental attitudes, environmental movements (of which environmental justice is a subset), the political economy of the environment and sustainable development, which reflects the global lens of environmental sociology. Some sociologists adopt the position of critical realism for asserting the real causal powers' of actors and social structures thus allow biophysical events causing changes in social processes and human interventions causing greenhouse gas emissions and global warming (C.S.A. (Kris) van Koppen 2017;.Archer et al. 2013; Elder-Vass 2012).

The second theme, research on the environmental justice studies, look at the disproportionate impact of environmental externalities on the lower classes, racial minorities and disempowered populations. Studies with a focus on race look at environmental racism. Scholars such as Robert Bullard (1992) and Beverly Wright (1998), as well as civil activists, are working to document environmental racism, and to develop mediation policies that prevent higher risks of exposure to toxic chemicals in residential communities of racial minorities. For instance, the 1982 official decision to dispose of 3,200 cubic yards of soil contaminated by toxic chemicals in the AfricanAmerican community of Afton, North Carolina was a pivotal incident in the environmental justice movement (Bullard and Wright, 1986). Thus, environmental racism and classism are both subsumed in the use of the term environmental justice.

The third theme, sociological work on the political economy of the environment, represents the third major topic in environmental sociology. Schnaiberg's (1980) work and Schnaiberg and his students (Schnaiberg and Gould 1994; 
Weinberg, Pellow, and Schnaiberg 2000) on the treadmill as a symbol of capitalist cornucopia are central to this field. The treadmill represents the forces perpetuating economic growth in advanced capitalist industrial societies. The increasingly dominant role of monopoly, global pollution, natural resources scarcity and the displacement of labour is at the heart of the production treadmill. State officials support the treadmill, even though environmental and labour problems grow, because corporate expansion provides the crucial taxable wealth essential for the financial life of the state (Lewis and Humphrey (2005). Thus, the political economy of growth becomes an important area in the field.

The fourth key area of environmental sociology involves research on sustainable development. For development to be sustainable, the environment should be protected, people's economic situation improved, and social equity enhanced (Humprey, Lews, and Buttel 2002: 225; Schnaiberg 1997). The idea of sustainable development was popularized with the 1987 Bruntland Commission Report, sponsored by the United Nations, which tied economic development to environmental protection, rather than posing them as adversaries.

\section{Role of Classical Theorists in Nature and Society:-}

Timo Jarvikoski special issue paper, titled "The relation of nature and society in Marx and Durkheim", published in the Journal of the Scandinavian Sociological Association (1996), points out the two great classical sociologists' role in nature and society. Jarvikoski (1996) stated that, since its inception, the discipline of "environmental sociology" has questioned the role of its classical figures concerning nature and society. Today's, many leading environmental sociologists such as Catton (1992:437), Dublap and Catton (1979:244), Buttel (1987) claim that classical theorists were blind to the relationship between environment and society. Timo Jarvikoski (1996) notes that many of Durkheim's works did not give importance to the word 'nature', rather he used concepts like 'physical milieu' and 'organism'. Durkheim's own writing from his popular book 'The Elementary forms of the Religious Life' (1978) precisely addressed:

Even if society is a specific reality it is not an empire within an empire; it is part of nature, and indeed its highest representation. The social realm is a natural realm which differs from the others only by a greater complexity.

(Durkheim, 19252 ed. Rev. 1976:18)

To elaborate the above quotation, it is very clear that the classical theorist Emile Durkheim had seen society as a part of nature, albeit of the highest complexity. Thus, it demonstrates that traditional or classical theorists were well aware of the connectivity of nature and society.

Another famous book by Durkheim, titled "The Division of Labour in Society" mentioned that an animal is almost completely dependent on the physical environment, while for human beings, particularly in developed societies, social factors become more important than biological or physical factors (1893, 1984:315-317). Here, it seems Durkheim has given priority to social issues over the physical environment. In response to this, Timo Jarvikoski (1996, p.80) says that "it is unfair to say that Durkheim completely rejected the influence of the physical environment, but he certainly makes clear that social causes and factors are much more important." To support Durkheim's explanation to physical environment, Jarvikoski (1996) has given an example from Durkheim's same book, where Jarvikoski had mentioned that the position of the physical environment as a precondition for social life is apparent in the following extract:

Man depends upon only three kinds of environment: the organism, the external world and society. If we set aside chance variations due to the combinations of heredity - and their role in human progress is certainly not very considerable - the organism is not modified spontaneously; it must be constrained to do so by some external cause. As for the physical world, from the very dawn of history this has remained appreciably unchanged, if at least we take no account of innovations of social origin. (Note: transformation of the soil, the waterways, by the skill of farmers, engineers, etc.) Consequently there is only society that has changed enough to be able to explain the parallel changes in the nature of the individual. (Durkheim 1893, 1984: 285-286).

Above quote clearly explains the stability of nature. In contrast, it seems Durkheim saw no problems in the changing of nature. He saw change as some kind of improvement, whose social advantages were without question. According to Timo Jarvikoski (1996), Durkheim did not problematize environmental changes from the sociological point of view. As Jarvikoski addressed that the reasons for this may be found in the strong belief in science, and the idea that different disciplines possessed territories of their own, so that there was no point in entering the fields of natural and technical science. 


\section{Durkheim as a social constructionist.:-}

Through this approach, Durkheim has an influence on contemporary sociology and anthropology, including environmental studies (Douglas 1978, Tester 1991). As Jarvikoski quoted from Durkheim's book titled "The elementary forms of religious life" (1976:p. 85) states that Durkheim argued that culture in a way provides the instruments, or shall we say the spectacles, for viewing nature. Durkheim pointed that, it is not central, from the point of view of sociology, what nature is 'really' like. It is important how the culture 'sees' nature. Thus Durkheim, in fact, spoke about the social or cultural construction of nature. Therefore, to conclude, Durkheim's role in environmental sociology is obvious from the relations between physical environment and social environment or between nature and society that is in abundance in his works.

\section{Karl Marx (1818-1883):-}

Although, the debate on the role of classical theorists in environment and nature still exists, recently many environmental sociologists have appreciated Marx's work, such as his concept about the dialectic of man and nature. Pepper (1993) in his book "Eco-Socialism" points out that Marx's discussion about materialism, which is capitalism, takes place in one of the greatest books "Early Writings". Here, Marx mentioned that capitalist system is a practical degradation of nature (Marx, 1952, Early Writings, p.7). However, some accuse Marx and Engels of too positive a view on industrialism and the belief in economic and social progress (Eckersley 1993).

\section{Man Part of Nature:-}

Marx makes clear that human beings are part of nature:

Nature is man's inorganic body - nature, that is, insofar as it is not itself human body. Man lives on nature meaning that nature is his body, with which he must remain in continuous interchange if he is not to die. That man's physical and spiritual life is linked to nature means simply that nature is linked to itself, for man is a part of nature. (Economic and philosophic Manuscript of 1844; Collected works Vol.3:276)

From the above quotes it is clearly indicated that in his writing man's active contact with nature and man's relation to the natural world is not theoretical but practical.

Another writing of his book titled "The German Ideology" quotes:

... the unity of man with nature has always existed in industry... according to the lesser or greater development of industry, and so has the 'struggle' of man with nature. (The German Ideology; Collected Works Vol.5.5:40)

The above quote clearly explains that there is nothing solemn in speaking of man's unity with nature. The unity or struggle depends on the industrial development which leads to degradation of environment or nature. Marx acknowledges that the natural conditions - the differentiation of the soil, the variety of its natural products, the changes of season - form the physical basis for the social division of labour. They also - (Marx, Capital vol.1)-

.... by changes in the natural surroundings, spur man on to the multiplication of his wants, his capabilities, his means and modes of labour. It is the necessity of bringing a natural force under the control of society, of economizing, of appropriating or subduing it on a large scale by the work of man's hand, that first plays the decisive part in the history of industry. (Marx (1867) 1959:481)

According to Jarvikoski (1996), Marx did not want to speak about nature as separate from humans; on the contrary, nature interested him mainly as a constituent element of human practice. According to Marx, a certain kind of antagonism exists between man and nature, as dependency on nature restricts human freedom.

\section{Degradation of the environment:-}

Engels was one of the first social theorists to call attention to the environmental damage caused by human societies, most importantly in the Dialectics of Nature, but also in his early work where he emphatically described environmental problems in the working-class districts in England (Engels (1844) 1962: 323-334). Marx argued in his writing 'Capital' - that capitalist production ... develops technology, and the combining together of various processes into a social whole, only by sapping the original sources of wealth - the soil and labourer. (1952:249-250).

Marx frequently blamed capitalist production for the interruption of the man-nature metabolism (Marx (1867)1957:474), but he also identified large scale industry and agriculture as the main causes of ecological 
problems. Marx himself noted (1867)1959:475) that 'There are two main sources of all wealth, the soil, and labour power. If man wants to prosper, these two also have to prosper.'

When working on Capital in the early 1860s, Marx was deeply affected by Liebig's (a German Chemist) contribution in agricultural and biological chemistry. In 1866, he wrote to Engles that in developing his critique of capitalist ground rent,

"I had to plough through the new agricultural chemistry in Germany, in particular Liebig and Schonbein, which is more important for this matter than all the economists put together" (Marx and Engels 1975, vol

$$
\text { 42.227). }
$$

Indeed "to have developed from the point of view of natural science the negative, thus destructive side of modern agriculture," Marx was noted that it is one of the Liebig immortal merits" (Marx, 1967, p638). Far from having ecological blinders with regard to the exploitation of the earth, Marx, under the influence of Liebig's work of the late 1850 s and early 1860 s, was to develop a systematic critique of capitalist "exploitation" of the soil (Foster, 1999p.379).

\section{Conclusion:-}

In sum, environmental sociology studies come across the causes of environmental problems, the impacts of such problems, and the solutions to these problems. In addition, it's classical theorist's contribution to this realm still need to do more research, not just saying they did not put their concentration to nonsocial conditions like the relationship in environment or nature and society.

\section{References:-}

1. Allan Schnaiberg (2002) Reflections on my 25 years Before the Mast of Environment and Technology Section.” Environment \& Organization, 15: 30-41.

2. Archer, M., R. Bhaskar, A. Collier, T. Lawson, and A. Norrie. (2013). Critical Realism: Essential Readings. Milton Park: Routledge.

3. Boström, M., A. M. Jönsson, S. Lockie, A. Mol, and P. Oosterveer (2015). "Sustainable and Responsible Supply Chain Governance: Challenges and Opportunities." Journal of Cleaner Production 107: 1-7

4. Bullard Robert (1992) "The quest for environmental Equity: Mobilizing the African -American Community for Social Change.” Pp. 39-50. In American Environmentalism: The U.S. Environmental Movement, 1970-1990, edited by Riley E. Dunlap and Angela G. Mertig. Philadelphia, PA: Taylor \& Francis.

5. Buttel, F.H. (1987). New Directions in Environmental Sociology. Annual Review of Sociology, 13.465-488.

6. C.S.A. (Kris) van Koppen (2017) Incorporating nature in environmental sociology: a critique of Bhaskar and Latour, and a proposal, Environmental Sociology, 3:3, 173-185,

7. Callon, M., and J. Law. (1989). "On the Construction of Sociotechnical Networks: Content and Context Revised." Knowledge and Society 8: 57-83.

8. Dickens, P. (1996). Reconstructing Nature. Alienation, Emancipation and the Division of Labour. London: Routledge.

9. Douglas, M. (1978). Implicit meanings. Essays in Anthropoogy. London: Routledge.

10. Du Toit, J. T. (2002). Sustainable wildlife utilization in Africa: A contest between scientific understanding and human nature. In P. Schmuck \& W. Schultz (Eds.), Psychology of sustainable development (pp. 197-208). Norwell, MA: Kluwer.

11. Dudley, W. (2001). The environment opposing viewpoints. San Diego :Greenhaven Press.

12. Dunlap \& Rosa. (2000). Environmental Sociology. Encyclopedia of Sociology. Volume 2, Second edition, p.800-815.

13. Dunlap \& William R. Catton, Jr. (1979) "Environmental Sociology.” Annual Review of Sociology 5:243-273.

14. Dunlap, R. E. (1993). "From Environmental to Ecological Problems." In Social Problems, edited by C. Calhoun and G. Ritzer, 707-737. New York: McGraw-Hill.

15. Durkheim, E. (1925 2 ed. rev.) 1976. The Elementary forms of religious life. Second edition, London: George Allen \& Unwin.

16. Durkheim, Emile $(1893,1984)$. The division of labour in Society. Basingstoke: Macmillan.p. 315-317.

17. Eckersley, R. (1993). Environmentalism and Political Theory. Toward an Ecocentric Approach. London: Routledge.

18. Elder-Vass, D. (2012). The Reality of Social Construction. Cambridge: Cambridge University Press.

19. Evernden, N. (1993). The Natural Alien. Humankind and Environment. Toronto: University of Toronto Press

20. Foster, John Bellamy (1999) "Marx's Theory of Social-Ecological Metabolism and the Critique of Capitalist Society: Classical Foundations for Environmental Sociology." American Journal of Sociology: 105:366-405. 
21. Frederick Buttel (2002). Environmental sociology and the sociology of natural resources: Institutional histories and intellectual legacies. Society \&Natural Resources, 15(3), 205-211.

22. Humphery; Lewis, and Buttel (2002) Environment, Energy, Society: A new Synthesis. Belmount CA, Wordsworht Thomson Learnings.

23. Irwin, A. (2013). Sociology and the environment: a critical introduction to society, nature and knowledge. John Wiley \& Sons.

24. Jarvikoski, T. (1996). The relation of nature and society in Marx and Durkheim. ACTA SOCIOLOGICA, vol. 36 (1), p.73-86.

25. Krogman and Darlington (1996) Sociology and the environment: An analysis of the Journal Coverage. The American Sociologist, 27:39-55.

26. Latour, B. (1993). We Have Never Been Modern. Cambridge: Harvard University Press.

27. Lewis and Humphrey (2005) Sociology And The Environment: An Analysis of Coverage In Teaching Sociology; Apr $2005 ; 33,2 ; 154-16$

28. Lockie, S. (2016). Sustainability and the future of environmental sociology.

29. Loren Lutzenhiser (2002) Environmental Sociology: The very idea. Organization and environment. 15: 5-9

30. Marx, K. (1952) Capital. Great Books of Western World. Capital by Karl Marx Manifesto of the Communist party by Karl Marx and Fridrich Engels. Chicalgo: William Benton.

31. Marx. K. (1867) 1959. Capital, Vol,1, Moscow: foreign Languages publishing house.

32. Nicolini, D. (2012). Practice Theory, Work, and Organization: An Introduction. Oxford: Oxfor University Press.

33. Pepper, D. (1993). Eco-socialism. From Deep Ecology to Social Justice. London and New York, Routledge.

34. Rudel, Thomas (2002). Sociologists in the Service of Sustainable Development? NGOs and the Environment Society Studies in the Developing World." Society and Natural Rsources, 15:263-8.

35. Schnaiberg, L. (1997). Firms hoping to turn profit from charters. Education Week, 1, 14.

36. Schnaiberg and Gould (1994). Environment and Society: The Enduring Conflict. New York: St. Martin's Press.

37. Schnaiberg, Allan (1980) The Environment from surplus to scarcity. New York. Oxford University Press.

38. Shapin, S., and S. Schaffer. (1985). Leviathan and the Air-Pump. Hobbes, Boyle and the Experimental Life. Princeton NJ: Princeton University press.

39. Shove, E., M. Pantzar, and M. Watson. (2012). The Dynamics of Social Practice. Everyday Life and How It Changes. London: Sage.

40. Sodero, S., and M. Stoddart (2015). “A Typology of Diversion: Legitimating Discourses of Tourism Attraction, Oil Extraction and Climate Action in Newfoundland and Labrador." Environmental Sociology 1 (1): 59-68.

41. Spaargaren, G. (1997). The Ecological Modernization of Production and Consumption: Essays in Environmental Sociology. Wageningen: Dissertations Wageningen University.

42. Stets, J. E., \& Biga, C. F. (2003). Bringing identity theory into environmental sociology. Sociological Theory, 21(4), 398-423.

43. Taylor, Dorceta E. (1997) "American Environmentalism: The Role of Race, Class and Gender in Shaping Activism, 1820-1995.' Race, Gender and Class 5:16-62.

44. Tester, K. (1991). Animals and Society: The humanity of animal rights. London: Routledge.

45. Järvikoski, T. (1996). The relation of nature and society in Marx and Durkheim. Acta sociologica, 39(1), 73-86.

46. UNDP: United Nations Development Program (2005). Human development report 2005. International cooperation at a crossroads; aid, trade and security in an unequal world. New York: 18 Vlek and Steg Human Development Report Office. Retrieved March 8, 2006 from http://hdr.undp.org/reports/global/2005/pdf/hdr05 summary.pdf.

47. UNEP: United Nations Environment Program (2006). AEO: Africa Environment Outlook. Nairobi, Kenya: UNEP, and London: Earthscan.

48. Vaillancourt Jean Guy. (1995). Sustainable development: A sociologist view of the definition, origins and implications of the concept. In Mehta, Michael D. \& Ouellet,Eric (Eds.) Environmental Sociology: Theory and Practice. Canada: Captus press inc.

49. Van Der Heijden, H. A. (1998). Gert Spaargaren, The Ecological Modernization of Production and Consumption: Essays in Environmental Sociology. ENVIRONMENTAL POLITICS, 7, 168-168.

50. Vlek, C., \& Steg, L. (2007). ๑ Human Behavior and Environmental Sustainability: Problems, Driving Forces, and Research Topics. Journal of social issues, 63(1), 1-19.

51. Weinberg, Pellow, and Schnaiberg (2000) Urban recycling and the search for sustainable Community Development. Princeton, NJ: Princeton University Press. 